\title{
EVALUASI ENERGI METABOLIS, KECERNAAN PROTEIN, ZAT TEPUNG, DAN SEPULUH BIJAN LEGUM PADA AYAM PEDAGING
}

\author{
K. G. Wiryawan' dan J.G. Dingle ${ }^{2}$
}

\section{INTISARI}

Energi metabolis, kecernaan protein dan kecernaan zat tepung 10 jenis kacang legume dievaluasi pada ayam pedaging umur tiga minggu. Satu bagian tepung kacang dicampur dengan dua bagian air dan diberikan kepada ayam dengan bantuan 'syringe' plastik diikuti dengan koleksi kotoran selama $24 \mathrm{jam}$. Energi metabolis, kecernaan protein dan kecemaan zat tepung kacang arab cv. Kaniva dan cv. Desi lebih tinggi dan untuk kacang hitam (black gram) dan kacang gude lebih rendah dari kacang babi (faba bean), kacang hijau, lentil, lupin, kacang kapri (field pea) and bungkil kedelai. Secara umum ada korelasi positif antara energi metabolis dan kecernaan zat tepung $(r=0.70$, $\mathrm{P}=0.0001)$ dan antara energi metabolis dan kecernaan protein $(\mathrm{r}=0.57, \mathrm{P}=0.0001)$. Hasil yang diperoleh menunjukkan bahwa setiap zat dalam biji legum yang menghambat pencernaan zat tepung dan atau protein akan menurunkan nilai energi metabolis. Disimpulkan bahwa energi metabolis biji legum berkurang bila kecernaan protein dan kecernaan zat tepung berkurang dan tingkat penurunannya tergantung pada kandungan tannin dan seratnya.

(Kata kunci : Kecernaan, energi, Zat tepung, Protein, Kacang, Ayam pedaging).

Buletin Peternakan $29(1): 19-25,2005$

\footnotetext{
'Fakultas Peternakan, Universitas Mataram, Mataram.

${ }^{2}$ Departemen Peternakan, Universitas Queensland Gatton, Australia.
} 


\title{
EVALUATION OF TRUE METABOLIZABLE ENERGY AND DIGESTIBILITY OF PROTEIN AND STARCH OF TEN GRAIN LEGUMES IN MEAT CHICKENS
}

\begin{abstract}
True Metabolizable Energy (TME), True Protein Digestibility (TPD), and Starch Digestibility (SD) of ten grain legumes were measured in 3 week old meat chickens. The chickens were hand fed a mixture of one portion of legume meal and two portions of water using a plastic syringe followed by a $24 \mathrm{~h}$ collection of droppings. TME, TPD, and SD of chickpea cv. Kaniva and chickpea cv. Desi were generally higher and those of black gram and pigeon pea were significantly lower than faba bean, green gram, lentil, lupin, field pea and soybean meal (SBM). Positive correlations were obtained between TME and SD $(r=0.70, P=0.0001)$ and between TME and TPD $(r=0.57, P=0.0001)$. These results suggest that any constituent in grain legumes which inhibits the digestibility of starch and/or protein would result in a decrease in TME value. Both the level of tannin and of the amount of Neutral Detergent Fibre (NDF) were significantly negatively correlated with TME, TPD and SD. In conclusion, the TME, TPD, and SD of grain legumes were significantly different. The chickpea cv. Kaniva was the best source of energy and protein but black gram, faba bean and lupin showed the lowest values for chickens. Tannin and cell wall components play a significant role in decreasing the TME, TPD and SD of grain legumes.
\end{abstract}

(Key words : Digestibility, Energy, Starch, Protein, Beans, Peas, Chickens).

\section{Introduction}

Screening tests for ten grain legumes found that their protein quality was high [chickpea, cv Kaniva (Cicer arietinum), chickpea cv. Desi (Cicer arietinum), and solventextracted soybean meal, (SBM) (Glycine max)], medium [green gram (Phaseolus aureus), field pea (Pisum sativum), pigeon pea (Cajamus cajan)] and low [lupin (Lupinus angustifolius), faba bean (Vicia faba) and black gram (Phaseolus mungo)] (Wiryawan and Dingle, 1995a). It was suggested that the factors responsible for low quality in legumes were methionine deficiency and the presence of anti nutritional factors. Results of the study on methionine supplementation showed that net weight gain (NWG) of chickens fed legume as the sole source of protein increased $(\mathrm{P}<0.001)$ as the level of dietary methionine increased (Wiryawan and Dingle, 1995b). When the methionine was present at $100 \%$ recommended allowance, the NWG of chickens fed the chickpea cv. Kaniva and the lentil diets were in the vicinity of 16 and $5 \%$ higher than those fed SBM, whereas net weight gain of chickens fed the black gram, chickpea cv. Desi, field bean, field pea, green gram, lupin and pigeon pea diets were $78,12,45,32,37$ and $38 \%$ lower than those fed the soybean meal diet. It is likely that the protein quality measured as net weight gain was a result of the combined effect of methionine deficiency and variation in metabolisable energy value. Edwards and Campbell (1991) emphasized that the response of poultry to dietary protein is limited by dietary energy.

The reported apparent metabolizable value of some grain legumes for chickens varied from $8 \mathrm{MJ} \mathrm{kg}^{-1}$ for pigeon pea and high-fibre containing chickpea (Tangtaweewipat and Elliot, 1989) to as high as $13.8 \mathrm{MJ} \mathrm{kg}^{-1}$ for low-fibre containing chickpea (Miller and Holmes, 1992). It should be noted that variation may exist not only among legumes but also between bird type (Slinger et al. 1964) and assay procedures (McNab, 1996). Therefore the ME of a feedstuff should be assayed using the target animals for which the feedstuff is to be used.

Variation in ME value may be associated with variation in starch digestibility. Mollah et al. (1983) in their studies on ME of wheat, suggested that in most cases, variation in AMEn 
is entirely accounted for by variation in starch and protein digestibilities. In line with those finding, Longstaff and $\mathrm{McNab}$ (1987) observed a good correlation between TME value of faba bean with starch digestibility. This suggests that any component of the ingredient that reduces starch digestibility would reduce the ME value since about $50 \%$ of dietary energy metabolized by poultry is derived from starch (Yutste et al. 1991). The purpose of this study was to determine the TME value in relation to the starch and nitrogen digestibilities, the tannin and NDF of ten grain legumes in young chickens.

\section{Materials and Methods}

\section{Test materials}

Black gram, chickpea cv. Kaniva, chickpea cv. Desi, faba bean, field pea, lentil, lupin, pigeon pea, and SBM were supplied by a local (Queensland/Australian) grain supplier. All grain legumes were ground to pass a $1 \mathrm{~mm}$ screen.

\section{Bird management and excreta collection}

One hundred and ninety seven-day-old male commercial meat chickens which had been reared in a group were randomly allocated to individual cages. The chickens were fed a commercial starter diet up to day 20 then left for $24 \mathrm{~h}$ without feed to empty their alimentary canals of feed residues. The rapid method of TME determination of Sibbald (1979) was applied with modification since free feeding presented problems such as in recovering feed lost in the faecal collection tray and drinking water. Modification was made in that chickens were tube-fed a mixture of one portion of legume meal to two portions of water using a plastic syringe. It required only about $10-15$ seconds to fill the crop with the feed mixture. Each test material was fed to six replicates of three chickens each. Four groups of three birds were left without feed to derive a mean value of endogenous energy and nitrogen loss.

A plastic tray was placed under each cage and the time recorded. The precise amount of test material consumed was the difference between the weight of the chicken before and after feeding. The excreta was collected for $24 \mathrm{~h}$ after feeding, dried at $60^{\circ} \mathrm{C}$ for $18-24$ hours, left at room temperature for $24 \mathrm{~h}$, weighed and ground to pass a $0.8 \mathrm{~mm}$ screen and kept for analyses of their gross energy, protein and starch contents

The TME and TPD values for each replicate were calculated using the following equations:

$$
\begin{aligned}
& \operatorname{TME}(\mathrm{MJ} / \mathrm{kg})=\frac{E I-E D+E E L}{F I} \\
& \operatorname{TPD}(\%)=\frac{\mathrm{PI}-(\mathrm{PF}-\mathrm{EPL})}{\mathrm{PI}} \times 100 \\
& \operatorname{SD}(\%)=\frac{\mathrm{SI}-\mathrm{SF}}{\mathrm{SI}} \times 100
\end{aligned}
$$

where EI = Energy intake; ED = Energy in droppings; $\mathrm{EEL}=$ Endogenous energy lost of unfed birds; $\mathrm{FI}=$ Feed intake; $\mathrm{EPL}=$ Endogenous protein lost; $\mathrm{PI}=$ protein intake; $\mathrm{PF}=$ Faecal protein; SI $=$ Starch intake; and $S F=$ Faecal starch.

\section{Analytical method}

The content of dry matter (DM), crude fat, and NDF of test materials and excreta were determined following standard procedures (AOAC, 1984). Nitrogen (N) content was analysed in an automatic nitrogen analyser using the combustion method (Sweeney, 1989). The faecal $N$ was calculated as total $N$ minus uric acid N. Crude protein (CP) content was calculated as $\mathrm{NX} 6.25$ and uric acid was determined according to the method of Marquardt (1983). Energy of feed and faeces was determined using a bomb calorimeter, using benzoic acid as standard and correcting for total acid production as determined by titration with $0.0709 \mathrm{~N}$ sodium carbonate solution. The starch content of the legume meals and faecal samples were calculated from the amount of glucose released after enzymatic hydrolysis by amyloglucosidase (EC. 3.2.1.3) as described by Longstaff and $\mathrm{McNab}$ (1991). 
Table 1. Nutrient content, Tannins, NDF and Trypsin Inhibitors Activity (TIA) in Grain Legumes ( $\mathrm{mg} \mathrm{g}^{-1}$ air-dry weight)

\begin{tabular}{|c|c|c|c|c|c|c|c|}
\hline Legume & $\mathrm{DM}^{*}$ & $\begin{array}{l}\text { Crude } \\
\text { protein }\end{array}$ & $\begin{array}{l}\text { GE } \\
\left.\text { (MJ kg } \mathrm{kg}^{-1}\right)\end{array}$ & Starch & Tannins ${ }^{\top}$ & NDF & $\begin{array}{l}\text { TIA } \\
\text { (TUI) }\end{array}$ \\
\hline Black gram (Phaseolus mungo) & 903.7 & 249.9 & 15.27 & 347.5 & 16.22 & 148.4 & 5.44 \\
\hline Chickpea cy Desi (Cicer arietinum) & 903.4 & 193.2 & 15.91 & 214.0 & 0.62 & 234.2 & 5.32 \\
\hline Chickpea cy Kaniva (Cicer arietinum) & 902.6 & 188.9 & 16.49 & 226.5 & 0.51 & 108.5 & 4.45 \\
\hline Faba bean (Vicia faba) & 908.6 & 234.7 & 15.85 & 372.1 & 2.53 & 209.6 & 2.52 \\
\hline Field pea (Pisum sativum) & 906.1 & 223.6 & 15.23 & 416.4 & 0.61 & 177.6 & 2.57 \\
\hline Green gram (Phaseolus aureus) & 899.3 & 223.5 & 15.43 & 444.3 & 2.10 & 139.9 & 3.68 \\
\hline Red lentil (Lens culinaris) & 893.9 & 239.0 & 15.16 & 422.2 & $<0.1$ & 138.2 & 2.10 \\
\hline $\begin{array}{l}\text { Lup in cv. gan gguru (Lupinus } \\
\text { angustifolius) }\end{array}$ & 916.4 & 313.5 & 16.61 & - & 1.53 & 239.4 & $<1$ \\
\hline Pigeon pea (Cajanus cajan) & 885.1 & 181.4 & 14.84 & 405.0 & 2.64 & 195.7 & 3.33 \\
\hline Soybean meaI $I^{\dagger}$ (Glycine max) & 888.0 & 454.5 & 16.13 & - & 0.49 & 164.9 & 2.51 \\
\hline
\end{tabular}

All from Wiryawan and Dingle (1995).

NDF $=$ Neutral Detergent Fibre, TUI $=$ Trypsin

Unit Inhibited $\mathrm{mg}^{-1}$ sample

Tannins content expressed as catechin equivalent

Table 2. True metabolizable energy (TME), true nitrogen digestibility (TND), and starch digestibility (SD) of some grain legumes ingrowing chickens.

\begin{tabular}{lccc}
\hline \hline \multicolumn{1}{c}{ Legume } & $\begin{array}{c}\text { TME } \\
\left(\mathrm{MJ} \mathrm{kg}^{-1}\right)\end{array}$ & $\begin{array}{c}\text { TPD } \\
(\%)\end{array}$ & $\begin{array}{c}\text { SD } \\
(\%)\end{array}$ \\
\hline Black gram & & & $78.64^{\mathrm{c}}$ \\
Chickpea cv. Desi & $9.39^{\mathrm{d}}$ & $67.21^{\mathrm{e}}$ & $86.96^{\mathrm{d}}$ \\
Chickpea cv. Kaniva & $13.25^{\mathrm{cd}}$ & $81.96^{\mathrm{a}}$ & $95.03^{\mathrm{a}}$ \\
Faba bean & $15.09^{\mathrm{a}}$ & $80.29^{\mathrm{ab}}$ & $90.26^{\mathrm{bc}}$ \\
Eield pea & $10.16^{\mathrm{d}}$ & $65.51^{\mathrm{e}}$ & $93.52^{\mathrm{ab}}$ \\
Green gram & $12.01^{\mathrm{c}}$ & $70.88^{\mathrm{ede}}$ & $89.76^{\mathrm{be}}$ \\
Lentil & $13.74^{\mathrm{b}}$ & $78.10^{\mathrm{abc}}$ & $93.62^{\mathrm{ab}}$ \\
Lupin & $13.38^{\mathrm{b}}$ & $71.88^{\mathrm{bcde}}$ & $\mathrm{nm}$ \\
Pigeon pea & $9.67^{\mathrm{d}}$ & $69.44^{\mathrm{de}}$ & $79.05^{\mathrm{d}}$ \\
SBM & $10.22^{\mathrm{d}}$ & $75.88^{\mathrm{abcd}}$ & $\mathrm{nm}$ \\
\hline SEM & $12.94^{\mathrm{cd}}$ & $79.17^{\mathrm{abc}}$ & 1.32 \\
\hline
\end{tabular}

SEM = Standard error means; ${ }^{\text {nm }}$ not measured.

${ }^{\text {sbodef }}$ Different superscripts in the same columns are significant differences $(\mathrm{P}<0.05)$.

of trypsin inhibitor in legume meals, but tannin content may have significantly reduced protein digestibility. Digestibility of protein was negatively correlated with tannin content $(r=$ $0.31, \mathrm{P}=0.019)$. Ortiz et al. (1993) showed that the digestion of faba bean protein by young chicks was significantly affected by the level of tannin in the diet. They reported that inclusion of freeze dried tannin at $1.6 \%$ into a chick diet resulted in an $8 \%$ reduction of ileal digestibility of protein.

Apart from starch digestibility (SD) of SBM and lupin, the SD's of grain legumes were significantly different from each other. Yutste et 
al. (1991) reported that the pea and bean starch digestibilities in chicks were 94 and $78 \%$ respectively, which was slightly lower than those obtained with cockerels. SD of black gram and pigeon pea were significantly $(\mathrm{P}<0.05)$ lower than SD of other legumes. Over $93 \%$ of starches of field pea, chickpea cv. Kaniva and lentil were digestible in young chickens. SD of chickpea cv. Desi, green gram and faba bean were significantly lower than those of chickpea $\mathrm{cv}$. Kaniva but significantly greater than those of black gram and pigeon pea. The correlation analysis confirmed that reduced starch digestion was related to tannin $(r=-0.62, P=0.0001)$ and $\mathrm{NDF}$ contents $(\mathrm{r}=-0.30, \mathrm{P}=0.04)$. Difference in SD of chickpea cv. Desi and SD of chickpea cv. Kaniva might be due to differences in their content of amylase inhibitor. Singh et al. (1982) reported that the level of amylase inhibitors in chickpea cv. Desi was greater than those of chickpea cv. Kabuli, and that was negatively correlated with in vitro starch digestibility.

The positive correlations obtained between TME and SD $(r=0.70, P<0.0001)$ and between TME and TPD $(r=0.57, P=0.0001)$ suggest that any component in grain legumes which inhibits digestibility of starch and/or protein would result in a decrease in TME value. The level of tannin induced a greater negative effect on $\mathrm{SD}(\mathrm{r}=-0.64 ; \mathrm{P}=0.0001)$ than on TPD $(\mathrm{r}=-0.31 ; \mathrm{P}=0.02)$. The possible mechanism by which tannin exerts its negative effects is through the formation of insoluble complexes with carbohydrates and proteins and/or through formation of complexes between tannin and digestive enzymes. The formation of tanninstarch complexes has been shown to decrease the in vitro amylolysis of several legumes and other starches (Deshpande and Salunkhe, 1982) and the tannin-protein complexes, which are extremely hydrophobic (Hagerman and Butler, 1980; Mitaru et al. 1984), were partly responsible for low protein digestibility. Intensive studies by Longstaff and McNab (1991) on effect of tannin showed that diets with tannin-rich hulls of faba bean caused a large reduction in the digestion of amino acids, starch and lipid compared with the control diet mainly due to inactivation of digestive enzymes by the formation of tannin-enzyme complexes in the digestive tract. Tannins inactivated trypsin the most, alpha-amylase to a lesser extent and lipase the least and therefore lowered the digestion of amino acids the most, starch to a lesser extent and lipid the least.

The cell wall component (NDF) also contributed to a lesser extent to the decrease in $\mathrm{SD}(\mathrm{r}=-0.30, \mathrm{P}=0.043)$ and $\mathrm{TND}(\mathrm{r}=-0.23, \mathrm{P}=$ $0.088)$.

In conclusion, the TME, TPD, and SD of grain legumes were significantly different. The chickpea cv. Kaniva was the best source of energy and protein but black gram, faba bean and lupin showed the lowest values for chickens. Tannin and cell wall components play a significant role in decreasing the TME, TPD and SD of grain legumes.

\section{References}

Association of Official Analytical Chemists. 1984. Official Methods of Analysis, $14^{\text {th }}$ Edn. AOAC. Washington, DC.

Brillouet, J. M, X. Rovav, C. Hoebler, J. L. Barry, B. Carre, and E. Lorta. 1988. A New Method for Determination of Insoluble Cell Walls and Soluble Nonstarchy Polysaccharides From Plant Materials. J. Agric. Food Chem. 36, 969-979.

Deshpande, S. S. and D. K. Salunkhe. 1982. Interaction of Tannic Acid and Catechin with Legume Starches. J. Food Sci. 47, 2080-2083.

Edwards, A. C. and R. G. Campbell, 1991. Energy-Protein Interaction in Pigs. In Recent Advances in Animal Nutrition, pp. 3-19 [W Haresign and DJA Cole, editors]. Oxpord, Butterworth-Heinemann.

Hagerman, A. E. and L. G. Butler. 1980. Condensed Tannin Purification and Characterisation of Tannin-Associated Protein. J. Agric. Food Chem. 28, 947952.

Kakade, M. L., J. J. Rackis, J. E. McGhee, and G. Puski. 1974. Determination of Trypsin Inhibitor Activity of Soy Product: a Collaborative Analysis of An Improved Procedure. Cereal Chem. 51,376-382. 
Lever, M. 1972. A New Reaction for Calorimetric Determination of Carbohydrates. Anal. Biochem. 47, 273279.

Longstaff, M. A. and J. M. McNab. 1987. Digestion of Starch and Fibre Carbohydrates in Peas by Adult Cockerels. Br. Poult. Sci. 28, 261 - 285.

Longstaff, M. A. and J. M. McNab. 1991. The Inhibitory Effects of Hull Polysaccharides and Tannin of Faba Beans (Vicia Faba L.) on the Digestion of Amino Acids, Starch and Lipid and on Digestive Enzyme Activities in Young Chicks. Br. J. Nutr. $65,199-216$.

Marquardt, R. R. 1983. A Simple Spectrophotometric Method for the Direct Determination of Uric Acid in Avian Excreta. Poult. Sci. 62, 2106-2108.

McNab, J.M. 1996. Factors Affecting the Energy Value of Wheat for Poultry. World's Poult. Sci. 52, 69-73.

Miller, H. M. and J. H. G. Holmes. 1992. Grain Legumes for Broiler Production. Proc. Aust. Poult. Sci. Sym. 3, 38-45.

Mitaru, B. N,, R. D. Reichert, and R. Blair. 1984. The Binding of Dietary Protein by Sorghum Tannins in the Digestive Tract of Pigs. J. Nutr. 114, 1787-1796.

Mollah, Y., W. L. Bryden, I. R. Wallis, D. Balnave, and E. F. Annison. 1983. Studies on Low Metabolizable Energy Wheats for Poultry Using Conventional and Rapid Assay Procedures and the Effects of Processing. Br. Poult. Sci. 24, 81-89.

Ortiz, L. T., C. Centeno, and J. Trevino. 1993. Tannins in Faba Beans Seeds; Effects on the Digestibility of Protein and Amino Acids in Growing Chicks. Anim. Feed Sci. Technol. 41:271-278.

Price, L. M., S. V. Scoyoc, and L. G. Butler. 1978. A Critical Evaluation of the Vanillin Reaction as an Assay for Sorghum Grain. J. Agric. Food Chem. 26, 1214- 1218.

Reddy, N. R., M. D. Pierson, S. K. Sathe, and D.
K. Salunkhe. 1984. Chemical, Nutritional, and Physiological Aspects of Dry Bean Carbohydrates: A Review. Food Chem. 13, 25-68.

Reddy, N. R., M. D. Pierson, S. K. Sathe, and D. K. Salunkhe. 1985. Dry Bean Tannins: a Review of Nutritional Implications. J. Am. Oil Chem. Soc. 62, 541-549.

Rhone Poulenc Animal Nutrition (1989) Nutrition Guide, 1st edn. Rhone Poulenc Commentary.

Saini, H. and T. Batterham. 1988. Trypsin And Chymotrypsin Activity in Cereals and Legumes. Proceedings of Pig Branch Conference, 12 - 15 September 1988. North Coast Agricultural Institute, Wollongbar.Pp.: 117-123.

Valdebouze, P., E. Bergeron, T. Gaborit, and J. Delort-Laval. 1980. Content and Distribution of Trypsin Inhibitors and Haemagglutinins in Some Legume Seeds. Can. J. Plant Sci. 60, 695-701.

Wiryawan, K. G. and J. G. Dingle. 1995a. Screening Test of the Protein Quality of Grain Legumes for Poultry Production. Br. J. Nutr. 74, 671-679.

Wiryawan, K. G. and J. G. Dingle. 1995b. Protein Quality of Grain Legumes for Chickens: Effect of Methionine Supplementation. Proc. Nutr. Soc. Aust. 19: 203.

Yutste, P., M. A. Longstaff, J. M. McNab, and C. McCorquodale. 1991. The Digestibility of Semipurified Starches From Wheat, Cassava, Pea, Bean, and Potato By Adult Cockerels and Young Chicks. Anim. Feed Sci. Technol. 35, 289-300.

\section{Acknowledgments}

The research was supported by the Egg Industry Research and Development Council of Australia. Mr. A. Lisle is thanked for statistical advice and Mrs. Rai Asih and Ms. K. Vockenson are thanked for their technical assistance. 